\title{
Bingöl Halkının Yeşil Alan Kullanımı ve Kent Parkları Yeterliliklerinin Değerlendirilmesi
}

\author{
Hüccet VURAL ${ }^{1} *$ \\ ${ }^{1}$ Bingöl Üniversitesi, Ziraat Fakültesi, Peyzaj Mimarlığı Bölümü,12000, BİNGÖL
}

\section{Öz}

İnsanlar, kent hayatının getirdiği zorluklarla baş etme, fiziksel ve ruhsal bakımdan dinlenebilmek için çeşitli sosyal alanlara ihtiyaç duyarlar. Bu alanların en başında kentsel yeşil alanlar gelmektedir. Yapılan çok sayıda araştırma, yeşil alanların çok yönlü katkılarını ve kent hayatı için önemini ortaya koymaktadır. Ancak yeşil alanların kendinden beklenen fonksiyonları ve kullanıcı ihtiyacını karşılayabilmesi için, ideal büyüklükte, erişilebilir ve estetik ve fonksiyonel bakımdan nitelikli olması gerekmektedir. Araştırmanın amacı, Bingöl halkının yeşil alanlardan yararlanma biçimlerini ve mevcut parkların ihtiyacı karşılama düzeylerini belirlemektir. Nitel ve nicel araştırma yöntemlerinin kullanıldığı araştırmada, saha incelemeleri yapılmış ve veri toplama amacıyla anket formu oluşturulmuştur. Anket, kent parklarında, katılımcıların işyerinde ve evlerinde farklı demografik yapıdan gönüllü 610 kişiyle yüz yüze yapılmıştır. Anket sonuçları, SPSS 22 programında betimselkategorik analiz yöntemleri ile fark testleri (Mann-Whitney U ve Kruskal Wallis H) kullanılarak analiz edilmiştir. Araştırma bulguları kent merkezinde bulunan yeşil alanların nitelik ve nicelik bakımından yetersiz olduğu gibi, kullanıcı ihtiyacını da karşılayamadığını göstermiştir. Anket sonuçlarına göre katılımcıların \% $\% 4,1$ 'i en yakın parkın 0-1 km mesafede olduğunu, \%58,2'si ise kentte bulunan yeşil alanların yetersiz olduğunu belirtmişlerdir. Ayrıca araştırma alanında bulunan kent parkları temel fonksiyon alanlarının yeterliliği üzerine yapılan değerlendirmenin 1,66 ile 2,73 puan arasında gerçekleştiği görülmüştür. Sonuç olarak, Bingöl kenti yeşil alanlarının kullanıcı ihtiyaçları doğrultusunda yeniden gözden geçirilmesi ve yeni yapılacak parkların evrensel peyzaj tasarım kuralları çerçevesinde planlanmasının gerekli olduğu vurgulanmaktadır.

Anahtar Kelimeler: Bingöl parkları, fonksiyon alanları, erişilebilirlik, yeşil alan memnuniyeti, peyzaj tasarımı.

\section{The Evaluations of Bingöl Public on Green Area Usage and Qualifications of Urban Parks}

\begin{abstract}
People need various social spaces in order to cope with the challenges of urban life and to be able to relax physically and spiritually. The most important of these areas is the urban green areas. Numerous researches have revealed the multi-faceted contributions of green spaces and their importance for urban life. However, in order to meet the expected functions and user needs of the green spaces, they should be ideally sized, accessible, aesthetically and functionally qualified. The aim of the study is to determine the usage of green areas of Bingöl people and the level of meeting the needs of these existing parks. Qualitative and quantitative research methods were used in the study, field surveys were conducted, and a questionnaire was created for data collection. The survey was conducted face-to-face with 610 volunteers from different demographic structures within the urban parks, participants' workplaces and homes. The results of the survey were analyzed by using descriptivecategorical analysis methods and difference tests (Mann-Whitney U and Kruskal Wallis H) in SPSS 22 program. The findings of the study showed that the green areas in the city center were insufficient in terms of quality and quantity and they could not have met the user needs. According to the survey results, $74.1 \%$ of the participants stated that the nearest park was $0-1 \mathrm{~km}$ away and $58.2 \%$ stated that the green areas in the city were insufficient. In addition, the evaluation of the adequacy of the main function areas of urban parks in the research area was found to be between 1.66 and 2.73 points. As a result, it is emphasized that the green areas of Bingöl should be revised in line with the needs of the user and new parks should be planned within the framework of universal landscape design rules.
\end{abstract}

Keywords: Bingöl parks, function areas, accessibility, green area satisfaction, landscape design. 


\section{Giriş}

Hızlı nüfus artışı sonucu meydana gelen kentleşme kentlerin sürekli olarak genişleyerek büyümelerine neden olmaktadır. Kentlerin beklenmeyen genişlemeleri ekolojik ortamların (orman, mera, toprak, su alanları, vb.) yerini beton ve asfalt gibi yapay ve geçirimsiz yüzeylerin alması sonucunu doğurmaktadır (Chen vd., 2018). Bu durum fiziki çevrede mekânsal, sosyal, ekonomik ve çevresel güçlükleri beraberinde getirmekte, aynı zamanda insan sağlığı ve yaşam kalitesi üzerine olumsuz sonuçlar doğurmaktadır. Sağlıksız ve plansız kentsel büyüme; çevre kirliliği, gürültü kirliliği, görüntü kirliliği, iklim değişikliği, habitat kayıpları, biyoçeşitliliğin azalması, gibi birbirlerini etkileyen küresel ölçekli problemlerle insanların yüz yüze kalmasına neden olmaktadır. Dünya Sağlık Örgütü'nün 2012 yılında hazırladığı rapora göre hava kirliliğinden yedi milyon insanın hayatını kaybetmesi ve gürültü kirliliği nedeniyle 60.000 insanın iskemik kalp hastalığı nedeniyle ölümü, konunun ciddiyetini ortaya koymaktadır (Gozalo vd., 2018). Bu nedenle kent ölçeğinde sağlık risklerinin azaltılması ve halkın refahını artırıcı önlemlerin alınması gerekmektedir.

Kentsel yeşil alanlar, kentsel hastalıklarla mücadele etme ve şehir sakinlerine, özellikle de sağlıklarına yardımcı olabilecek çok çeşitli ekosistem hizmeti sunmaktadır (Wolch vd., 2014; Demiroğlu vd., 2017; Gozalo vd., 2018). Bununla beraber insanlar, kent hayatının getirdiği zorluklarla baş etme, iş hayatının oluşturduğu yorgunluktan kurtulabilme ve fiziksel ve ruhsal bakımdan dinlenebilmek için çeşitli sosyal alanlara ihtiyaç duyarlar. Bu alanların en başında kentsel açık-yeşil alanlar gelmektedir. Yapılan çok sayıda araştırma ile kentsel açık-yeşil alanların çok yönlü katkıları ortaya konmuştur. Genel olarak kente ve kent insanına sağladığı katkıları ve yerine getirdiği işlevleri; ekolojik, ekonomik, sosyolojik ve teknik işlevler olmak üzere dört grupta özetlemek mümkündür (Önder ve Polat, 2012).

Kentsel açık-yeşil alanların ekolojik işlevleri; oksijen üretmesi, hava kirliliğini azaltma-filtreleme, serinliksıcaklık vermesi, nem oranını düzenleme, atmosferdeki zehirli gazların zararlarını azaltma, erozyonu önleme, biyolojik çeşitlilik için ortam sunma, gürültü engelleme gibi çok sayıda işlevi yerine getirmesidir (Gül ve Küçük, 2001; Ülger ve Önder, 2006; Olgun, 2019. Yeşil alanların ekonomik işlevi; yeşil alanların, ormanların veya ağaçların ısıtma-soğutma ile enerji tasarrufu sağlaması (Yılmaz vd., 2006), kentsel altyapının iyileştirilmesi ile turizm potansiyelinin ve iş imkânlarının artması (Öztürk ve Özdemir, 2013), yeşil alanların hedonik etki oluşturması (Morancho, 2003; Saphores ve Li, 2012) ve birçok ürün için hammadde olması nedeniyle üretim olanağı sunmasıdır. Sosyal işlevi olarak halkın rekreasyon ihtiyacını karşılama başta olmak üzere, eğitim ve kültürel aktivitelerin gerçekleştirilmesine olanak sağlaması, halkın sağlığına olumlu katkısı ve suç oranlarının azalmasında rol aldığı belirlenmiştir (Grahn ve Stigsdotter, 2003; Bilgili vd., 2011; Öztürk ve Özdemir, 2013; Doygun vd., 2015; Gozalo vd., 2018). Ayrıca yeşil alanlar fiziki planlama ile ilgili birçok teknik işlevi de yerine getirmektedir (Önder ve Polat, 2012). Yeşil alanların teknik işlevlerinin başında mimari yapılarla uyumu ve kentin karakterini yansıtma potansiyeli gelmektedir (Gül ve Küçük, 2001). Bunun yanında olumsuz çevre şartlarının iyileştirilmesi, mimari etki, perdeleme, kent gelişim yönünün düzenlenmesi, vb. gibi çok sayıda teknik işlevleri de bulunmaktadır.

Açık-yeşil alanların nitelik ve nicelikleri gelişmiş ülkelerde kentin yaşam kalitesinin bir göstergesi olarak kabul edilmektedir (Gül ve Küçük, 2001). Kentin düzenli ve sağlıklı bir ortama kavuşmalarında açık-yeşil alanların kent içindeki dağılımları, büyüklükleri, işlevleri ve estetik özellikleri planlı ve programlı bir kentsel tasarım anlayışı içerisinde ele alınması ile mümkündür (Yavuz ve Eminağaoğlu, 2007). Bundan dolayı gelişmiş ülkelerin birçok kentinde halkın rekreasyonel, zihinsel ve fiziksel ihtiyacını karşılayacak nitelikte kent içerisinde veya bitişiğinde büyük kent parkları, bölge parkları, kent ormanları, koruluklar, yeşil kuşak sistemleri, vb. büyük ölçekli planlamalara yer verilmektedir.

Kentsel açık-yeşil alanların oluşturulmasında göz önünde bulundurulması gereken hususlardan biri de yaş gruplarının ihtiyaçları doğrultusunda ve çok yönlü planlanmasıdır. Planlama aşamasında ve sonrasında ihtiyaçların değişiklik göstermesi gerçeği ile güncellenmesi gerekmektedir. Bu bakımdan yetkili kurumlar tarafından bilimsel gelişmeler doğrultusunda belirli aralıklarla ihtiyaç ve gereksinimlerin belirlenmesi ve hem mevcut parkların yenilenmesinde hem de yeni parkların planlanmasında göz önünde bulundurulmalıdır. Bütün fiziki planlamalarda olduğu gibi yeşil alan planlamasında da temel hedef kullanıcı memnuniyetinin sağlanması olmalıdır. Bu hedef doğrultusunda çalışma alanı olarak belirlenen Bingöl kentinde günümüze kadar açık-yeşil alanların yeterliliklerini ve kullanıcı memnuniyetini ele alan bir çalışmanın yapılmamış olması bu araştırmanın yapılmasına dayanak oluşturmuştur.

Araştırmada Bingöl halkının yeşil alanlardan yararlanma biçimlerinin, erişilebilirliklerinin, tercihlerinin ve mevcut parkların ihtiyacı karşılama düzeylerinin demografik özelliklere göre belirlenmesi amaçlanmıştır. Araştırma sonuçlarının mevcut yeşil alanların iyileştirilmesine ve gelecekte yapılması planlanan çalışmalara 
yön vermesi beklenmektedir. Bunun yanında araştırmanın sürdürülebilir yeşil alan planlaması, sağlıklı ve yaşanılabilir mekânların yaratılması hedefi doğrultusunda kullanıcı farkındalığının ve yerel gündemin oluşmasına katkı sağlayacağı düşünülmektedir.

\section{Materyal ve Metot}

\subsection{Materyal}

Araştırma Türkiye'nin Doğu Anadolu Bölgesinde yer alan ve orta ölçekli büyüklükte olan Bingöl İli’nde yürütülmüştür. Kentin Türkiye İstatistik Kurumu Adrese Dayalı Nüfus Kayıt Sistemi (ADNKS)'e göre 2018 y1lı nüfusu 281.205 olup bu nüfusun 168.180'i kentsel (il ve ilçe merkezleri) bölgelerde, 113.025'i kırsal (belde, köy, vb.) bölgelerde ve 117.556'sı ise Bingöl kent merkezinde yaşamaktadır (TÜİK, 2019). Araştırmanın birincil verileri Bingöl kent merkezinde yaşayan ve 2019 yılı Mayıs-Haziran aylarında 610 kişi ile yapılan anket sonuçlarından elde edilmiştir. İkincil verileri ise Türkiye ve yurtdışında kent ölçeğinde yeşil alan yeterlilikleri konusunda yapılan çalışmalar, resmi kurum verileri (Bingöl Belediyesi'nden kent merkezinde bulunan parklarla ilgili elde edilen veriler) ve kentin mevcut yeşil alanlarında yapılan incelemeler sırasında tutulan notlar ve çekilen fotoğraflar oluşturmaktadır.

\subsection{Metot}

Araştırmada nitel ve nicel araştırma yöntemlerinin birlikte kullanıldığı karma araştırma yaklaşımından (açıklayıcı desen) yararlanılmıştır. Açıklayıcı desende temel veriler nicel sonuçlara dayanır. Nicel verileri desteklemek için nitel veriler toplanır (Creswell ve Plano-Clark, 2007). Bu amaçla nicel veri toplama aracı olarak anket formu oluşturulmuştur. Hazırlanan anket formu için uzman görüşü alınmış ve pilot uygulama yapılmıştır. Ayrıca etik kurul onayı (Bingöl Üniversitesi Bilimsel Araştırma ve Yayın Etik Kurul Başkanlığı'nın 21.06.2018 tarih ve 26 nolu kararı) alınmıştır. Hazırlanan anket yaş, cinsiyet, yerleşim yeri gibi bireysel özellikler dikkate alınarak kent parklarında ve katılımcıların ev ve işyerlerinde anketörler aracılığı ile MayısHaziran 2019 tarihlerinde yüz yüze yapılmıştır.

Örneklem büyüklüğünün hesaplanmasında;

$$
n=\frac{N \cdot P \cdot Q \cdot t_{\alpha, s d}^{2}}{(N-1) \cdot d^{2}}
$$

formülü kullanılarak oluşturulan tablodan yararlanılmıştır (Çıngı, 1994). Evren büyüklüğü 117.500, sapma miktarları ,04 olmak üzere farklı sapma miktarları için uygun örneklem tablosu minimum değeri olan 597'nin üzerine çıkılmıştır. Örneklemin belirlenmesinde seçkisiz örnekleme yöntemlerinden basit tesadüfi örnekleme yöntemi kullanılmıştır. Anket formu; katılımeı profilini belirleyen 9 soru, yeşil alan tercihlerini ve yararlanma biçimlerini belirleyen 9 soru ve yeşil alan niteliklerini belirleyen 15 soru olmak üzere toplam 33 sorudan oluşmaktadır. Anket sonuçlarının değerlendirilmesinde frekans, yüzde, ortalama değer, standart sapma gibi temel istatistik yöntemlerinin yanında kategorik verilerde Pearson Chi Square (Ki kare) testi, Likert ölçekli sorularda ise değişken sayısına bağlı olarak Mann-Whitney U Testi ve Kruskal Wallis H testi kullanılmıştır (Duymuş vd., 2012).

Araştırmanın nitel verileri Bingöl kent merkezinde bulunan 22 farklı parkta yerinde gözlem ve incelemelerle elde edilen bulgulara dayanmaktadır. Yapılan gözlem ve incelemelerde parkların fonksiyon birimleri ile ilgili notlar tutulmuş ve fotoğraflar çekilmiştir.

\section{Bulgular}

\subsection{Kentte Bulunan Parklar}

Araştırma kapsamında Bingöl kent merkezinde bulunan toplam 22 park incelenmiştir. İncelenen parkların alan büyüklüğü ve mahalleleri Tablo 1'de verilmiştir. İncelenen parklardan kapladığı alan bakımından en büyük park 2017 yılında hizmete açılmış olan Kent Parkı (41.882 m²), en küçük parkın ise Uzun Savak Parkı (1.374 $\mathrm{m}^{2}$ ) olduğu görülmektedir. 
Tablo 1. Araştırma alanında bulunan parklar ve alan büyüklükleri

\begin{tabular}{|c|c|c|c|}
\hline S.No & Parkın Adı & Mahallesi & Alan Büyüklüğü $\left(\mathrm{m}^{2}\right)$ \\
\hline 1 & Kent Park1 & Selahaddin Eyyubi & 41.882 \\
\hline 2 & Kültür Parkı & Eğitim Cad. Yenişehir Mah. & 35.000 \\
\hline 3 & Yüzenada Parkı & Recep Tayyip Erdoğan & 9.000 \\
\hline 4 & Çır Şelalesi Parkı & Recep Tayyip Erdoğan & 7.950 \\
\hline 5 & B. S. Nursi Park1 & Kültür Mahallesi & 7.740 \\
\hline 6 & Dörtyol Parkı & Genç Caddesi & 7.000 \\
\hline 7 & Mevlana Parkı & Recep Tayyip Erdoğan & 6.900 \\
\hline 8 & Sülbüs Park1 & Recep Tayyip Erdoğan & 6.900 \\
\hline 9 & Farabi Park1 & Recep Tayyip Erdoğan & 6.900 \\
\hline 10 & Mehmet Çibuk Parkı & Bahçelievler Mahallesi & 6.615 \\
\hline 11 & M.Fatih Safitürk Parkı & Recep Tayyip Erdoğan & 6.288 \\
\hline 12 & 15 Temmuz Şehitler Park1 & Saray Mahallesi & 6.000 \\
\hline 13 & İnalı Yamaç Parkı & İnalı Mahallesi & 6.000 \\
\hline 14 & Üçgen Park1 & Yeni Mahalle & 4.300 \\
\hline 15 & Sebze Hali Parkı & Şehit Mustafa Gündoğdu & 4.200 \\
\hline 16 & Hulusi Bey Parkı & Saray Mahallesi & 4.090 \\
\hline 17 & Karşıyaka Parkı & Karşıyaka Mahallesi & 4.021 \\
\hline 18 & Filistin Park1 & Yenişehir Mahallesi & 3.000 \\
\hline 19 & İnalı Mahalle Park1 & İnalı Mahallesi & 2.940 \\
\hline 20 & Simani Park1 & Simani Mahallesi & 2.830 \\
\hline 21 & Sağlık Parkı & Saray Mahallesi & 1.500 \\
\hline 22 & Uzunsavat Park1 & Şehit Mustafa Gündoğdu & 1.374 \\
\hline
\end{tabular}

Araştırma alanında yer alan 22 parkta yapılan incelemelerde parklarda bulunan fonksiyon birimlerinin birbirlerine benzer nitelikte olduğu görülmüştür (Şekil 1). Parkların hemen hemen tümünde çocuk oyun alanlarına ve açık-kapalı oturma birimlerinden oluşan oturma alanlarına park büyüklüğüne paralel olarak yeterli büyüklükte yer verildiği görülmüştür. Ancak yapılan düzenlemelerde parkların çok yönlü fonksiyonlarını karşılayacak içeriklere yer verilmediği görülmektedir. Özellikle parklarda eğitim içerikli alanlara, sosyal faaliyet alanlarına ve hobi amaçlı alanlara hemen hemen bütün parklarda rastlanmamıştır. Ayrıca parkların ekolojik içerikleri bakımından da arzu edilen seviyede olmadığı belirlenmiştir. Parkların nitelik ve nicelik bakımından yeterlilik düzeyleri üzerine yararlanıcı görüşleri çalışmanın ileriki bölümlerinde detaylı olarak yer verilmiştir.

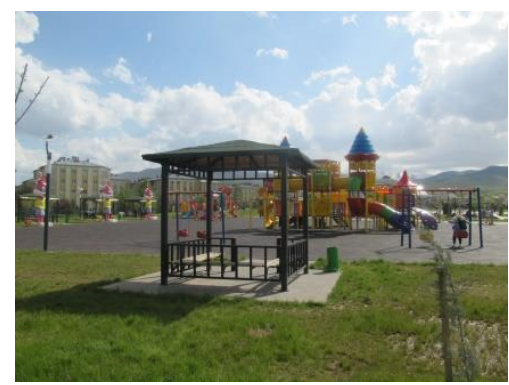

Kent park1

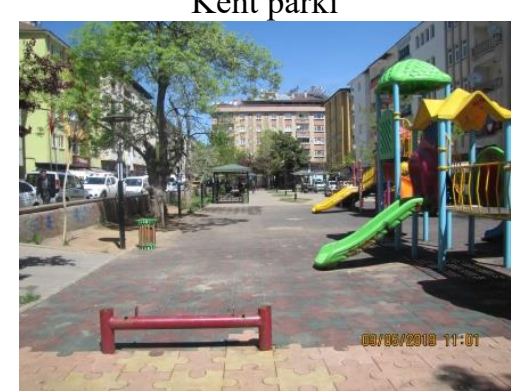

Filistin park1

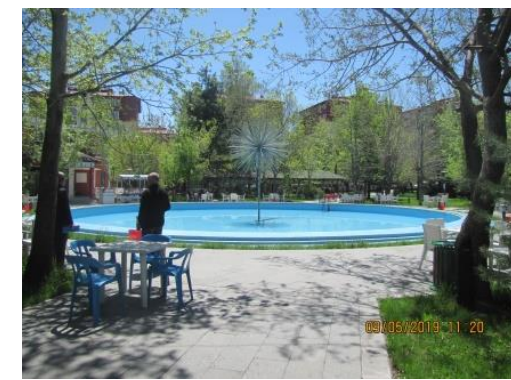

Kültür parkı

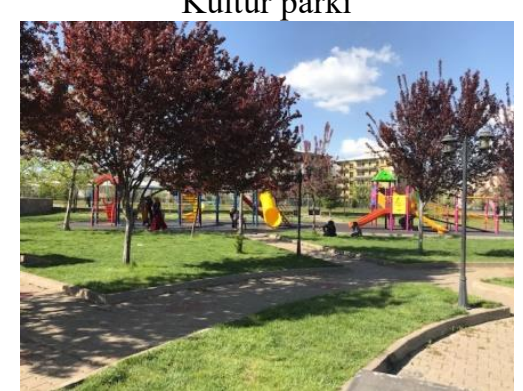

Karşıyaka parkı

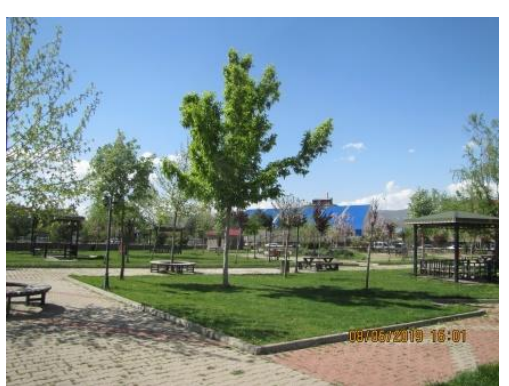

15 Temmuz park1

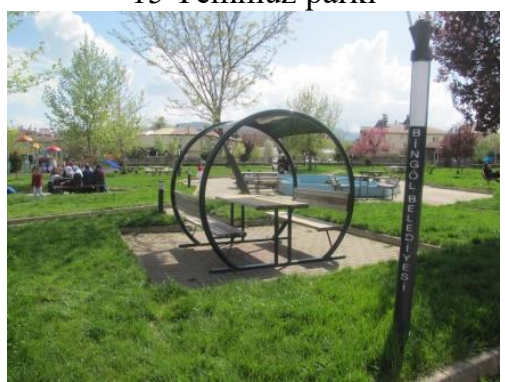

Sülbüs park1

Şekil 1. Araştırma alanında bulunan bazı parklardan görünümler 


\subsection{Anket Sonuçlarından Elde Edilen Bulgular}

\subsubsection{Katılımcı profilinin belirlenmesi}

Araştırma kapsamında yapılan anket çalışmasına katılan katılımcıların cinsiyet, medeni durum, yaş, eğitim durumu, meslek ve gelir gibi bireysel özellikleri ile ilgili veriler Tablo 2'de verilmiştir.

Tablo 2. Anket katılımcılarının bireysel özellikleri

\begin{tabular}{|c|c|c|c|c|}
\hline S.N & Soru & Seçenekler & Sayı (n) & Yüzde (\%) \\
\hline \multirow{2}{*}{1} & \multirow{2}{*}{ Cinsiyet } & Kadın & 319 & 52,3 \\
\hline & & Erkek & 291 & 47,7 \\
\hline \multirow{3}{*}{2} & \multirow{4}{*}{ Medeni hal } & Evli & 342 & 56,1 \\
\hline & & Bekâr & 243 & 39,8 \\
\hline & & Diğer (boşanmış, dul...) & 25 & 4,1 \\
\hline \multirow{4}{*}{3} & & $0-20$ Yaş & 85 & 14 \\
\hline & \multirow{3}{*}{ Yaş } & 21-35 Yaş & 296 & 48,8 \\
\hline & & $36-50$ Yaş & 194 & 32 \\
\hline & & 51 Yaşından büyük & 31 & 5,1 \\
\hline \multirow{5}{*}{4} & \multirow{5}{*}{ Eğitim durumu } & İlkokul mezunu veya altı & 84 & 13,8 \\
\hline & & Ortaokul mezunu & 71 & 11,6 \\
\hline & & Lise mezunu & 209 & 34,3 \\
\hline & & Yükseköğrenim mezunu & 214 & 35,1 \\
\hline & & Lisansüstü öğrenim mezunu & 32 & 5,2 \\
\hline \multirow{5}{*}{5} & \multirow{5}{*}{ Meslek } & Öğrenci & 146 & 24 \\
\hline & & Kamu personeli & 130 & 21,3 \\
\hline & & Kamu dışı ücretli çalışan & 45 & 7,4 \\
\hline & & Serbest meslek-Esnaf & 111 & 18,7 \\
\hline & & Çalışmiyor & 174 & 28,6 \\
\hline \multirow{4}{*}{6} & \multirow{4}{*}{ Gelir durumu } & Dar gelirli & 94 & 15,4 \\
\hline & & Orta gelirli & 350 & 57,4 \\
\hline & & İyi & 141 & 23,1 \\
\hline & & Çok iyi & 25 & 4,1 \\
\hline Toplam & & & & \\
\hline
\end{tabular}

Tablo 2'ye göre araştırmaya katılan bireylerin \%52,3'ü kadın, \%47,7'si erkek olup cinsiyet dışında diğer özelliklerde bazı grupların daha yüksek oranda yer aldığı görülmektedir. Medeni hal bakımından "evliler", yaş bakımından "21-35 yaş" bireyler, eğitim düzeyi bakımından "lise ve üniversite mezunları", meslek bakımından emekli, işsiz gibi grupların oluşturduğu "çalışmayan” bireyler ve gelir bakımından "orta gelirli” bireylerin diğer gruplara göre daha yüksek oranda temsil edildiği görülmektedir.

Araştırmada katılımcıların bireysel özelliklerinin yanında ikametgâh özellikleri de belirlenmiştir. Buna göre katılımcılar ikametgâhının \%14,1 "müstakil ev", \%54,1 "apartman dairesi”, \%25,2 "site içi daire" ve \%5,6 "sosyal tesis, otel, yurt..." olduğu görülmüştür. Bu ikametgâhlarda \%14 1 yıldan az, \%39,2 1-5 yıl arası, \%16,9 6-10 yıl ve \%29,9 10 yıldan fazla süredir oturduğunu beyan etmişlerdir. Katılımcıların Bingöl'de bulunma süreleri de belirlenmiştir. Buna göre \%58,5'inin 10 yıldan fazla, \%12,4'ünün 6-10 yıl arası, \%23,1'inin 1-5 yıl arası kentte bulunduğu \%6,1'inin ise 1 yıldan az veya misafir statüsünde yer aldıkları görülmüştür.

\subsubsection{Katılımcıların yeşil alan tercihleri ve yararlanma biçimleri}

Araştırma kapsamında katılımcıların yeşil alan tercihleri ve yararlanma biçimlerinin belirlenmesi amacıyla 9 kategorik soru yöneltilmiş ve sonuçların cinsiyet, medeni hal, yaş, eğitim, meslek ve gelir bakımından farklılıkları ki kare (Pearson Chi-Square) testi yardımıyla analiz edilmiştir. İlk olarak katılımcılara "Satın alacağınız konut seçiminizde park, yeşil alan, çocuk oyun alanı gibi kullanım alanlarına yakınlığı sizi etkiler mi?” şeklinde yöneltilen soruya \%64,9 “evet”, \%14,1 "hayır” ve \%21 "kısmen” cevabını vermiştir. Bu sonuçlar yeşil alana olan talebin yüksekliğini göstermektedir. Ancak talebin yukarıda belirtilen değişkenlere göre farklılık gösterip göstermediği ile ilgili yapılan ki kare analizinde sadece meslek gruplarına göre dereceli farkl1laştığ görülmektedir (Meslek grubu için x2=20,97, p<,05). Meslek grubu içerisinde diğer gruplara göre en yüksek talep $(\% 71,9)$ öğrencilerden, en düşük talep $(\% 49,3)$ ise serbest meslek sahiplerinden gelmiştir. 
Yeşil alanlardan yararlanmayı etkileyen en önemli faktörlerden birisi de erişilebilirliktir. Bu kapsamda katılımcılara evlerine en yakın park mesafesinin ne kadar olduğu sorulmuş ve Şekil 2'deki sonuçlar elde edilmiştir.

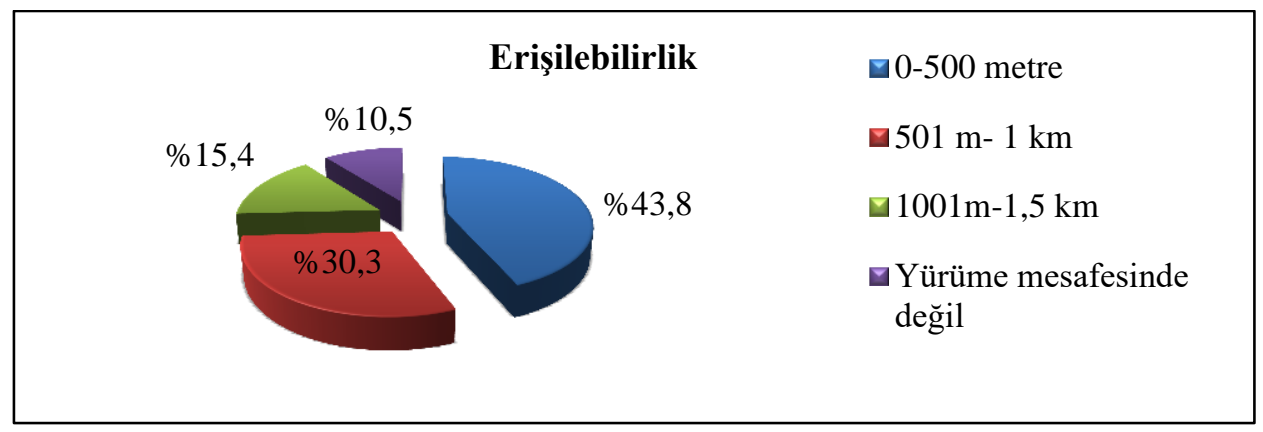

Şekil 2. Kent parklarına erişilebilirlik mesafesi

Ankete katılanların parklara olan mesafelerini; \%43,8'i 0-500 m mesafede, \%30,3'ü $501 \mathrm{~m}-1 \mathrm{~km}$ mesafede, \%15,4'ü 1001m-1,5 km mesafede ve \%10,5'i yürüme mesafesinde olmadığını vurgulamaktadır. Sonuçlar parklara erişilebilirlikle ilgili olumlu bir durumun olduğunu göstermektedir. "Satın alacağınızın konut seçiminizde park, yeşil alan, çocuk oyun alanı gibi kullanım alanlarına yakınlığı sizi etkiler mi?" sorusuna verilen cevaplar ile erişilebilirlik sonuçları arasında ilişkinin olup olmadığı ile ilgili yapılan ki kare analizinde anlamlı ilişki olduğu belirlenmiştir $\left(\mathrm{x}^{2}: 12,77\right.$, df: $\left.6, \mathrm{p}<, 05\right)$. Buna göre konut satın alımı ile yeşil alana yakınlığ arasında paralel ilişki bulunmaktadır. Katılımcıların konut alımı tercihinde yeşil alana yakınlığı ve erişilebilirliklerinin etkili olduğu görülmüştür.

Erişilebilirlikle ilgili katılımcılara yürüme mesafesinde park-mesire alanı ile çocuk oyun alanı olup olmadığ sorulmuştur. Katılımcıların \%61,6'sı park-mesire alanının, \%57,9'u çocuk oyun alanının yürüme mesafesinde olduğunu bildirmektedir. Ancak katılımcılar park ve oyun alanlarının yakın olmasına karşılık nitelik ve nicelik bakımından yetersiz olduğunu vurgulamaktadır. Buna göre ankete katılanların \%15,4'ü "büyüklük bakımından yetersiz, nitelik bakımından yeterli”, \%25,1'i "nitelik bakımından yetersiz, büyüklük bakımından yeterli”, \%39,9'u "hem büyülük hem de nitelik açısından yetersiz" olduğunu beyan etmişlerdir. Katılımcıların sadece \%19,6's1 nitelik ve nicelik bakımdan mevcut parkları yeterli bulmaktadır.

Araştırma kapsamında katılımcıların yeşil alanlardan yararlanma sebepleri ve yararlanma sıklığı da belirlenmiştir (Tablo 3).

Tablo 3. Katılımcıların yeşil alanlardan yararlanma sıklığı ve sebebi

\begin{tabular}{llcc}
\hline Sorular & Seçenekler & $\boldsymbol{n}$ & $\boldsymbol{\%}$ \\
\hline \multirow{4}{*}{ Yararlanma } & Her gün & 68 & 11,2 \\
Sıklığı & Haftada bir defa & 80 & 13,1 \\
& Haftada bir günden fazla & 117 & 19,2 \\
& İhtiyacım oldukça & 242 & 39,7 \\
& Sadece hafta sonları & 67 & 11 \\
& Hiç kullanmam & 35 & 5,7 \\
& Toplam & $\mathbf{6 0 9}$ & $\mathbf{1 0 0}$ \\
& Dinlenme, stres atma, temiz hava alma, serbestçe dolanma, & 410 & 27,6 \\
& doğa ile baş başa kalma,vb. & 262 & 17,6 \\
Yararlanma & & 23,4 \\
nedenleri & Sportif aktivite (spor yapma, yürüyüş, bisiklet sürme, koşma) & 347 & 21,2 \\
& Sosyal aktivite (sohbet etme, piknik yapma, yeme-içme) & 315 & 9,5 \\
& Çocuklarımı eğlendirmek & 141 & 10,7 \\
& Kitap okuma, kültürel faaliyette bulunma, vb. & 10 \\
& Diğer & $\mathbf{1 4 8 5}$ & $\mathbf{1 0 0}$ \\
\hline
\end{tabular}


Tablo 3'deki sonuçlar Bingöl halkının yeşil alana olan yoğun talebinin bir göstergesidir. Buna göre sadece katılımcıların \%5,7'si yeşil alanlardan hiç yararlanmadığını belirtmektedir. Bunun dışında \%94,3'ü belirli sıklıkta yeşil alanlardan yararlanmakta olduğunu bildirmiştir. Bunların içinde \%39,7'si belirli bir sıklıkta değil ihtiyaç oldukça yararlandığını ifade etmektedir. Katılımcılar \%67,2'sinin yeşil alanlardan dinlenme, stres atma, temiz hava alma, doğa ile baş başa kalma amacıyla yararlandığını bildirmektedir. Ancak kitap okuma ve kültürel faaliyette bulunma amacıyla parklardan yararlanmanın diğer seçeneklere göre düşük seyrettiği görülmektedir. Bu sonucun toplumun kültürel yapısı ile ilgili olabileceği kadar mevcut parkların bu fonksiyonu karşılamadaki yetersizliği ile de ilgili olabileceği düşünülmektedir.

Yeşil alan ve parklardan yararlanma sıklığında farklılık oluşturan değişkenlerin belirlenmesine yönelik yapılan ki kare testinde cinsiyet, medeni hal, yaş, meslek grubu ve aylık gelir değişkenliği ile yararlanma sıklığı arasında fark bulunmamıştır ( $p>0,05)$. Ancak eğitim düzeyi ve oturduğu konutun parka uzaklığı değişkenleri ile yararlanma sıklığı arasında fark anlamlı bulunmuştur. Eğitim düzeyi bakımından lise mezunları diğer gruplara oranla daha yüksek oranda parklardan yararlanmaktadır $\left(\mathrm{x}^{2}: 35,40\right.$, df: $\left.20, \mathrm{p}=0,02<0,05\right)$. Benzer olarak konut yakınlığı parklardan yararlanma sıklığını etkilediği görülmüştür. Parka yakın konutu olanlar beklendiği gibi daha fazla yararlanmaktadır. Konutun parka uzaklığı 0-500 m olan grup, yürüme mesafesinde park olmayan gruba göre 20 kat daha fazla parktan yararlandıkları görülmüştür $\left(\mathrm{x}^{2}: 51,21\right.$, df: $\left.15, \mathrm{p}=0,00<0,05\right)$.

Ankete katılanların bireysel özellikleri ile parklardan yararlanma nedenleri arasında anlamlı ilişkinin olup olmadığına yönelik yapılan testte Tablo 4'deki sonuçlar elde edilmiştir.

Tablo 4. Parklardan yararlanma sebebi ile değişkenler arasında ilişki

\begin{tabular}{|c|c|c|c|c|c|c|c|c|c|c|c|c|}
\hline \multirow{3}{*}{ Seçenekler } & \multicolumn{12}{|c|}{ Değişkenler } \\
\hline & \multicolumn{2}{|c|}{ Cinsiyet } & \multicolumn{2}{|c|}{ Yaş } & \multicolumn{2}{|c|}{$\begin{array}{c}\text { Medeni } \\
\text { hal }\end{array}$} & \multicolumn{2}{|c|}{ Meslek } & \multicolumn{2}{|c|}{$\begin{array}{l}\text { Gelir } \\
\text { düzeyi }\end{array}$} & \multicolumn{2}{|c|}{$\begin{array}{c}\text { Eğit. } \\
\text { Düzeyi }\end{array}$} \\
\hline & $x^{2}$ & $p$ & $x^{2}$ & $p$ & $x^{2}$ & $p$ & $x^{2}$ & $p$ & $x^{2}$ & $p$ & $x^{2}$ & $p$ \\
\hline $\begin{array}{l}\text { Serbest dinlenme, stres } \\
\text { atma, temiz hava alma, } \\
\text { doğa ile baş başa kalma, } \\
\text { vb. }\end{array}$ & 2,7 & ,09 & 3,2 & 36 & 1,5 & ,48 & 8,1 &, 15 & 2,6 & ,46 & 4,2 & ,39 \\
\hline Sportif aktivite & ,43 &, 51 & 3,4 &, 33 &, 10 &, 95 & 5,6 & ,34 & 15 &, $00^{*}$ & 6,9 &, 14 \\
\hline Sosyal aktivite & 01 & ,93 & 1,6 & ,66 & 84 & ,65 & 2,8 & ,73 & 0,8 & 85 & 2,5 & 64 \\
\hline Çocuklarımı eğlendirme & 1,4 &, 23 & 42 &, $00^{*}$ & 86 &, $00^{*}$ & 45 & $00^{*}$ & 7,3 & ,06 & 5,2 &, 27 \\
\hline $\begin{array}{l}\text { Kültürel aktivite, kitap } \\
\text { okuma }\end{array}$ & 7,5 &, $01^{*}$ & 8,3 &, $04^{*}$ & 3,7 & ,16 & 19, & $01^{*}$ & 6,2 &, 10 & 11,1 &, $02^{*}$ \\
\hline
\end{tabular}

Tablo 4'e göre "dinlenme, stres atma, temiz hava alma, serbestçe dolanma, doğa ile baş başa kalma" ile "sosyal aktivite (sohbet etme, piknik yapma, yeme-içme, vb.)" amaçlı parklardan yararlanma bakımından gruplar arasında fark bulunmamaktadır $(\mathrm{p}>0,05)$. Sportif aktivite amaciyla parklardan yararlanmada gelir düzeyi, çocukları eğlendirme amacıyla parklardan yararlanmada yaş, medeni hal ve meslek, kitap okuma amacıyla parklardan yararlanmada cinsiyet, yaş, meslek ve eğitim düzeyinin tercihlerde fark oluşturduğu görülmüştür $(\mathrm{p}<0,05)$.

\subsubsection{Kent parklarının yeterliliği ile ilgili değerlendirme}

Araştırmada katılımcılara standart bir parkta yer verilmesi gereken fonksiyon alanları ve donatı elemanlarının yeterliliği de sorulmuş ve Tablo 5'deki sonuçlar elde edilmiştir. 15 Likert ölçekli soru katılımcılar tarafından çok yetersiz (1 puan), yetersiz (2 puan), orta (3 puan), yeterli (4 puan) ve oldukça yeterli (5 puan) şeklinde puanlanmış ve ortalama değerleri hesaplanmıştır. Değerlendirme için belirli bir parkı veya il genelindeki tüm parkları değerlendirme seçeneği sunulmuştur. Böylece hem park özelinde ve hem de ilde bulunan tüm parklar için değerlendirme imkânı bulunmuştur. 
Tablo 5. Kent parklarının yeterliliği ile ilgili görüşler

\begin{tabular}{|c|c|c|c|c|c|c|c|c|c|c|c|c|}
\hline \multirow[t]{2}{*}{ Özellik } & \multirow[t]{2}{*}{$\mathbf{N}$} & \multicolumn{2}{|c|}{$\begin{array}{c}\text { Çok } \\
\text { Yetersiz }\end{array}$} & \multicolumn{2}{|c|}{ Yetersiz } & \multicolumn{2}{|c|}{ Orta } & \multicolumn{2}{|c|}{ Yeterli } & \multicolumn{2}{|c|}{$\begin{array}{l}\text { Oldukça } \\
\text { Yeterli }\end{array}$} & \multirow[t]{2}{*}{ Ort. } \\
\hline & & $f$ & $\%$ & $f$ & $\%$ & $f$ & $\%$ & $f$ & $\%$ & $f$ & $\%$ & \\
\hline $\begin{array}{l}\text { Ücretsiz oturma alanlar1- } \\
\text { oturma bankları }\end{array}$ & 594 & 95 & 16 & 155 & 26,1 & 205 & 34,5 & 92 & 15,5 & 47 & 7,9 & 2,73 \\
\hline $\begin{array}{l}\text { Yürüyüş-koşu yolları, } \\
\text { zeminin uygunluğu }\end{array}$ & 608 & 141 & 23,2 & 179 & 29,4 & 189 & 31,1 & 76 & 12,5 & 23 & 3,8 & 2,44 \\
\hline $\begin{array}{l}\text { Ücretli dinlenme, yeme- } \\
\text { içme alanları, kafe ve çay } \\
\text { bahçeleri }\end{array}$ & 606 & 160 & 26,4 & 159 & 26,2 & 187 & 30,9 & 72 & 11,9 & 28 & 4,6 & 2,42 \\
\hline $\begin{array}{l}\text { Donatı elemanları (Çöp } \\
\text { kovası, çeşme, } \\
\text { aydınlatma üniteleri, } \\
\text { yönlendirme levhaları, } \\
\text { vs.) }\end{array}$ & 608 & 165 & 27,1 & 181 & 29,8 & 179 & 29,4 & 74 & 12,2 & 9 & 1,5 & 2,31 \\
\hline $\begin{array}{l}\text { Sessiz dinlenme alanları } \\
\text { Bitkisel düzenlemeler }\end{array}$ & 595 & 158 & 26,6 & 186 & 31,2 & 181 & 30,4 & 61 & 10,3 & 9 & 1,5 & 2,29 \\
\hline $\begin{array}{l}\text { (gölgeleme, perdeleme, } \\
\text { görsel peyzaj etkisi, vb.) }\end{array}$ & 601 & 161 & 26,8 & 214 & 35,5 & 171 & 28,5 & 46 & 7,7 & 9 & 1,5 & 2,21 \\
\hline Bisiklet sürme olanakları & 610 & 214 & 35,1 & 178 & 29,2 & 138 & 22,6 & 67 & 11 & 13 & 2,1 & 2,16 \\
\hline $\begin{array}{l}\text { Her yaş grubu çocuk için } \\
\text { oyun alanları }\end{array}$ & 607 & 199 & 32,8 & 211 & 34,8 & 141 & 23,2 & 43 & 7,1 & 13 & 2,1 & 2,11 \\
\hline Hobi amaçlı alanlar & 609 & 243 & 39,9 & 213 & 35 & 116 & 19 & 27 & 4,5 & 10 & 1,6 & 1,93 \\
\hline $\begin{array}{l}\text { Diğer üniteler (otopark, } \\
\text { büfe, WC, lavabo, vs.) }\end{array}$ & 606 & 252 & 41,6 & 194 & 32 & 121 & 20 & 33 & 5,4 & 6 & 1 & 1,92 \\
\hline $\begin{array}{l}\text { Spor alanlar1 (basketbol, } \\
\text { futbol, voleybol, fitness, } \\
\text { vb.) }\end{array}$ & 610 & 250 & 41 & 213 & 34,9 & 116 & 19 & 29 & 4,8 & 2 & 0,3 & 1,90 \\
\hline $\begin{array}{l}\text { Su yüzeyleri, süs } \\
\text { havuzları, su elemanları } \\
\text { Kültürel faaliyet alanları }\end{array}$ & 607 & 266 & 43,8 & 207 & 34,1 & 95 & 15,7 & 34 & 5,6 & 5 & 0,8 & 1,86 \\
\hline $\begin{array}{l}\text { (sergi-konser-tiyatro } \\
\text { alanları, gösteri } \\
\text { alanları..) }\end{array}$ & 609 & 290 & 47,6 & 206 & 33,8 & 96 & 15,8 & 15 & 2,5 & 2 & 0,3 & 1,74 \\
\hline $\begin{array}{l}\text { Eğitim içerikli alanlar } \\
\text { (hayvanat, botanik } \\
\text { bahçeleri, satranç } \\
\text { alanları, labirent, vs) }\end{array}$ & 610 & 350 & 57,4 & 155 & 25,4 & 71 & 11,6 & 28 & 4,6 & 6 & 1 & 1,66 \\
\hline Genel değerlendirme & 608 & 205 & 33,7 & 207 & 34 & 148 & 24,4 & 42 & 6,9 & 6 & 1 & 2,07 \\
\hline Ortalama & 610 & & & & & & 2,12 & & & & & \\
\hline
\end{tabular}

Fonksiyon alanları ve donatı birimlerinin yeterliliği ile ilgili yapılan puanlamanın 1,66 ile 2,73 arasında değiştiği görülmüştür. Eğitim içerikli alanlar en yetersiz, oturma-dinlenme alanları ise diğerlerine göre daha yeterli bulunmuş, genel ortalama 2,12 olarak hesaplanmıştır. Katılımcıların "genel değerlendirme" puan ortalamaları ile 14 fonksiyon alanı ortalama değerlerinin birbirine yakın olduğu görülmüştür. Bu durum anket sonuçlarının güvenirliğine katkı sağlamıştır. Ayrıca katılımcıların bütün parametrelerle ilgili değerlendirmelerinin “orta” puanın altında puanlandığı görülmüştür. Değerlendirmede 6 parametre çok yetersiz ile yetersiz arasında, 8 parametre ise yetersiz ile orta arasındadır.

Yukarıda belirtilen fonksiyon alanlarının ve donatıların yeterliliği ile ilgili park özelinde yapılan değerlendirmede kentin en büyük parkları (Kültür parkı, Kent parkı, B. S. Nursi parkı ve 15 Temmuz Şehitler parkı) ile diğer küçük parkların ortalama memnuniyet değerleri hesaplanmıştır (Şekil 3). 


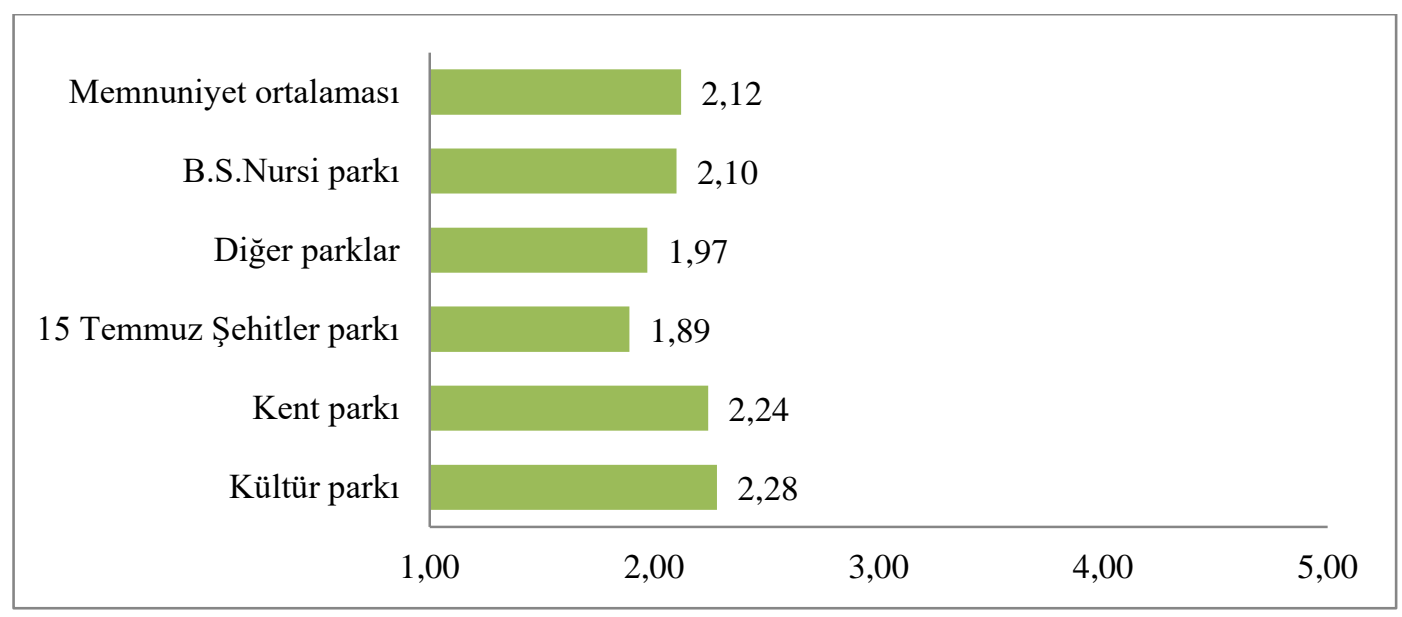

Şekil 3. Park özelinde kullanıcı memnuniyeti ortalama değerleri

Şekil 3'e göre Kültür parkı ve Kent parkının kullanıcı gereksinimlerini karşılama bakımından diğer parklara göre daha iyi durumda olduğu belirlenmiştir. Kentin en eski parkı olan Kültür parkı en yeterli park olarak değerlendirilmiştir. En yakın tarihte yapılan Kent parkının ise olması gereken puandan uzak olmasına karşılık ikinci sırada nitelikli park olduğu anket sonuçlarından anlaşılmıştır. Diğger tüm parklar için yapılan memnuniyet değerlendirmesinin ortalamanın altında puanlandığı görülmüştür.

Kent parklarının yeterliliği ile ilgili yapılan değerlendirmelerin cinsiyet, medeni hal, yaş ve meslek gruplarına göre değişiklik gösterip göstermediği de araştırma kapsamında incelenmiştir. Değişkenler bakımından farklılıkların belirlenmesinde kullanılacak test yöntemine karar vermek için öncelikle normal dağılım analizi yapılmıştır. Histogram, varyasyon katsayısı, çarpıklık-basıklık, detrended dağılımı ve Kolmogorov-Smirnov testinden oluşan 5 aşamalı normallik analizinde dağılımın normallik göstermediği anlaşılmıştır $(p<0,05)$. Bu durumda değişkenler bakımından sonuçların anlamlılık analizinde parametrik olmayan testlerin kullanılması gerekliliği ortaya çıkmıştır. Cinsiyet değişkeninin memnuniyete etkisinin belirlenmesinde bağımsız gruplar ttestinin parametrik olmayan alternatifi Mann-Whitney U Testi, medeni hal, yaş ve meslek gruplarının memnuniyete etkisinin belirlenmesinde ise Kruskal Wallis H testi kullanılmıştır (Duymuş vd., 2012).

Kentte bulunan parkların fonksiyon alanlarının yeterliliği ile ilgili 15 soru ortalamasına göre kadınlar 2,08, erkekler ise 2,16 ortalama değer üzerinden memnuniyetini ifade etmektedir. Bu farkın istatistik olarak anlamlılık düzeyleri Mann-Whitney U Testi kullanılarak analiz edilmiştir. 15 soru için ayrı ayrı yapılan analizde cinsiyete göre farklılık anlamlı bulunmamışen $(p>0,05)$ genel ortalamaya göre fark anlamlı bulunmuştur (Tablo 6).

Tablo 6. Cinsiyetin kent parklarından memnuniyete etkisi (Mann-Whitney U Testi sonuçları)

\begin{tabular}{clrllcc}
\hline Kriter & Cinsiyet & $\boldsymbol{N}$ & Stra ortalamast & Sira toplamı & $\boldsymbol{Z}$ & $\boldsymbol{P}$ \\
\hline Mem_ort & Kadın & 319 & 291,15 & 92876,00 & $-2,108$ &, $035^{*}$ \\
& Erkek & 291 & 321,23 & 93479,00 & & \\
\hline
\end{tabular}

$\overline{\mathrm{p}<0,05}$

Medeni hal, yaş, eğitim düzeyi ve meslek gruplarının memnuniyete etkisi Kruskal Wallis H testi kullanılarak analiz edilmiştir. Yapılan analize göre tüm değişkenlere göre yapılan değerlendirmelerde anlamlı bir sonuç bulunmamıştır ( $p>0,05)$. Bu değişkenlere göre yapılan değerlendirmenin homojen olduğu görülmektedir.

\section{Tartışma, Sonuç ve Öneriler}

Kentsel açık-yeşil alanlar ve parklar kent halkının yaşam standartlarını artıran, kente modern görünüm katan, kent halkının başta rekreasyon ihtiyaçları olmak üzere çok sayıda ihtiyacı karşılayan sosyal ve stratejik alanlar haline gelmiştir (Gül ve Küçük, 2001; Gürer ve Uğurlar, 2017). Geniş bir yelpazede yer alan paydaşlara çok sayıda kentsel hizmet sunma kapasiteleri nedeniyle, herhangi bir kentin yaşamsal parçalarıdır (Belmeziti vd., 
2018). İyi planlandığı zaman kentsel yeşil alanlarda kullanıcıların rekreasyon ihtiyaçlarının karşılanmasının yanında çeşitli sanatsal, sportif, eğitim amaçlı sosyal faaliyetlerin de gerçekleştirilmesi mümkündür. Bunun yanında özellikle kent parkları mahalle ölçeğinde halkın toplanma alanları olarak deprem ve yangın gibi doğal afetlerden korunma alanı olarak da kullanılma imkânı sunmaktadır. Ancak yeşil alanlar kendilerinden beklenen fonksiyonları yerine getirebilmeleri için çok yönlü planlanması gerekmektedir. Kent parklarının planlanmasında peyzaj mimarlığı prensipleri ve peyzaj tekniğine uygunluğunun yanında parkın büyüklüğü, yeri, hizmet ettiği alan ve erişilebilirliği de oldukça önem arz etmektedir.

Kentsel yeşil alanların belirli zaman aralıklarında yeterlilik analizinin yapılması, yeşil alan yönetimi ve gelecekte yapılacak tasarımları için önemlidir. Sahip olduğu sosyal, çevresel ve ekonomik fonksiyonları düşünülerek bu alanların korunması ve iyileştirilmesi gerekmektedir (Gozalo vd., 2018). Başta hızlı ve kontrolsüz kentleşme olmak üzere kentsel yeşil alanlar üzerine baskılar bir taraftan onların kaybına neden olurken diğer taraftan kentin yaşam kalitesinin düşmesine sebep olmaktadır (Chen vd., 2018).

Fiziki planlamalarda en öncelikli husus yapılan planlamanın kullanıcı istekleri doğrultusunda gerçekleştirilmesidir. Özellikle kentsel yeşil altyapının ana unsuru olan kent parklarının planlanma aşamasında kullanıcı ihtiyaç ve istekleri doğrultusunda yapılması onların daha fazla kullanılmasını ve işe yarar olmasına katk1 sağlayacaktır. Bunun yanında belirli aralıklarda kent parkları ile ilgili ihtiyaç analizlerinin yapılması gerekmektedir. Bu kapsamda yapılan araştırmada Bingöl ilinin yeşil alan varlığının yeterliliği, kullanıcı ihtiyaçlarını karşılama düzeyleri ve Bingöl ilinin yeşil alan ihtiyaçları belirlenmiştir.

Yeşil alan varlığı ile ilgili en temel gösterge kişi başına ne kadar aktif yeşil alan düştüğüdür. Aktif yeşil alanlar içerisinde ise en büyük pay kent parklarına düşmektedir. Araştırma alanında bulunan parklarının dağılımı ve büyüklüğü ile ilgili yapılan incelemelerde 1.500-41.882 $\mathrm{m}^{2}$ arasında değişen büyüklükte 22 park belirlenmiştir. Bu parkların tamamının toplam alan büyüklüğü $182.430 \mathrm{~m}^{2}$ olup kişi başına $1,55 \mathrm{~m}^{2}$ park alanı düşmektedir. Türkiye'nin değişik illerinde kişi başına düşen açık-yeşil alan miktarı ile ilgili yapılan çalışmalarla kıyaslandığında yeşil alan varlığında Türkiye genelinde bir sıkıntı olduğu görülmektedir. Bu çalışmalardan Gül ve Küçük (2001) Isparta kenti için $3 \mathrm{~m}^{2}$, Ülger ve Önder (2006) Kayseri kenti için $5.83 \mathrm{~m}^{2}$, Öztürk ve Özdemir (2013) Kastamonu kenti için $1.04 \mathrm{~m}^{2}$, Manavoğlu ve Ortaçeşme (2015) Antalya kenti için $4.2 \mathrm{~m}^{2}$ aktif yeşil alan hesaplamıştır. Oysa gelişmiş ülkeler ortalaması oldukça yüksektir (Yenice, 2012).

Türkiye kentleri için 14.06.2014 tarih ve 29030 sayılı Resmi Gazete'de yayımlanan "Planlı Alanlar İmar Yönetmeliği”" ekinde verilen tabloya göre kişi başına düşmesi gereken açık-yeşil alan miktarı nüfusa bakılmaksızın $15 \mathrm{~m}^{2}$ olarak öngörülmüş, bu miktarın $10 \mathrm{~m}^{2}$ s si ilçe sınırları içerisinde çocuk bahçesi, park, meydan, semt spor alanı, botanik park1, mesire yeri, rekreasyon alanı olarak ayrılması, $5 \mathrm{~m}^{2}$, si ise il sınırları içerisinde hayvanat bahçesi, kent ormanı, ağaçlandırılacak alan, fuar, panayır ve festival alanı, hipodrom alanı olarak planlanması öngörülmüştür (Resmi Gazete Tarihi: 14.06.2014 Resmi Gazete Sayıs1: 29030). Her ne kadar yönetmelikte sadece kent parkları için bir sınırlama getirilmemiş olsa dahi $10 \mathrm{~m}^{2}$ 'lik sınırlamada en büyük pay kent parklarına aittir. Bu bakımdan araştırma alanında yer alan parkların alan büyüklüğünün yönetmelikle belirlenen standartların çok uzağında olduğu görülmektedir.

Bir başka değerlendirmede ise parklar mahalle parkı, semt parkı, kent parkı, anakent park1 ve bölge parkı olarak adlandırılmakta ve alan büyüklügüune göre sınıflandırılmaktadır. Mahalle parkı için 40 da, semt parkı için 160 da, kent parkı için 1000 da, anakent parkı için 5000 da ve bölge parkı için 10000 dekarlık ideal büyüklük ortaya konulmaktadır (Atabeyoğlu ve Bulut, 2012; Manavoğlu, 2013). Buna göre araştırma alanında bulunan parklardan sadece Kent Parkı ve Kültür Parkı “mahalle parkı" statüsüne yakındır. Diğer parkların hiçbiri yukarıda belirtilen park statülerinden birine uymadığı görülmektedir. Alanda yapılan incelemelerden elde edilen bulgular da bu sonucu desteklemektedir. Parkların birbirine yakın nitelikte olduğu ve yararlanıcıların sınırlı sayıda aktivitesini destekler nitelikte olduğu görülmüştür.

Kent parklarının planlanmasında dikkate alınması gereken diğer bir husus erişilebilirliktir. Uygun erişilebilir mesafe halka yeşil alanlardan ve parklardan adil bir şekilde yararlanma olanağı sunmaktadır. Ayrıca yeşil alanların hedonik etkisi nedeniyle herkes için belirli mesafelerde yeşil alanların planlanması gerekmektedir. Çünkü yeşil alan mesafesi ile konutların satış fiyatları arasında ters yönlü bir ilişki bulunmaktadır (Bahrinia vd., 2017). Erişilebilirlikle ilgili temel standardın yürüme mesafesi olduğu, bunun çocuk oyun alanları için $400 \mathrm{~m}$ (10 dakika), semt-mahalle parkları için 800 m (20 dakika), kent parkları için 1200 m (30 dakika) olduğu Avrupa Komisyonu Denetim raporunda bildirilmektedir (Önder ve Polat, 2012). Araştırma alanında yer alan yeşil alanların ve çocuk oyun alanlarının erişilebilirliğinin belirlenmesi amacı ile ilgili katılımcılara sorular yöneltilmiştir. Elde edilen sonuçlara göre $1 \mathrm{~km}$ 'lik mesafe içerisinde yeşil alana sahip katılımcı oranı \% 74,1 'dir. Katılımcıların \%10,5’i yürüme mesafesinde bir park olmadığını bildirmektedir. Başka bir soruda ise yürüme 
mesafesinde park-mesire alanı imkânı bulan katılımcı oranı \%61,6, çocuk oyun alanı imkânına sahip katılımcı oranı \%57,9'dur. Bu sonuçlar Bingöl ilinde yeşil alana erişim konusunda biraz daha olumlu durumun olduğunu göstermektedir.

Araştırma alanında bulunan yeşil alanların yeterliliği ile ilgili katılımcıların yapmış olduğu değerlendirmede önemli oranda eksikliklerin olduğu görülmektedir. En başta katılımcıların büyük bir kısmı $(\% 89,5)$ kentin yeşil alan varlığını yeterli bulmadıklarını belirtmișlerdir. Bunun doğal bir sonucu olarak parklardan istedikleri oranda yararlanamadıkları görülmektedir. Yararlanmama nedeni olarak; katılımcıların \%30'u ideal bir parkın olmaması, \%49'u mevcut parkların nitelikli, bakımlı olmaması ve ihtiyacı karşılayamaması, \%11,5'i güvenlik açısından uygun olmaması, \%8,9’u çocukları için oyun imkânı sunmamasını göstermektedir.

Kentsel yaşam kalitesinin artırılmasında önemli rolü olan yeşil alanlarının başarısı ve yeterliliğinin belirlenmesinde alansal büyüklüğü yeterli değildir (Öztürk ve Özdemir, 2013). Parkların işlevlendirilmesi ve değerlendirilmesinde fonksiyonel yapı ve fiziksel/mekânsal yapı değerlendirilmelidir (Onsekiz ve Emür, 2008). Bir parkın niteliği fonksiyon alanlarının çeşitliliği ve ihtiyacı karşılama düzeyi ile doğrudan ilişkilidir. Bu kapsamda katılımcıların yapmış olduğu değerlendirmede fonksiyonel yapı ile fiziksel/mekânsal yapının kullanıcı memnuniyetini sağlamada oldukça yetersiz kaldıkları görülmektedir. Katılımcıların fonksiyon alanlarının yeterliliği ile ilgili 1-5 puan arasında yapmış olduğu değerlendirmenin 1,66 ile 2,73 puan arasında gerçekleştiği, ortalamalarının ise 2,07 olduğu görülmüştür.

Sonuç olarak Bingöl kentinin mevcut açık-yeşil alan varlığı hem nitelik hem de nicelik bakımından yeterli olmadığı, kullanıcı ihtiyacını karşılamaktan uzak olduğu ve yararlanıcı memnuniyetini karşılayamadığı belirlenmiştir. Bu sonuçlar doğrultusunda;

1. Kent için sürdürülebilir ve uzun dönemli yeşil alt yapı planının hazırlanması ve uygulanmaya başlanması,

2. Araştırma alanı için en az bir adet kent parkının planlanması, bunun için Çapakçur vadisinin kent içerisinde kalan kısmında imar planında rekreasyon alanı olarak gösterilen alanın kent parkı olarak değerlendirilmesi, Mevcut parklardan alan olarak büyütülme imkânı bulunan parkların genişletilmesi,

3. Mevcut parkların fonksiyonel yapısının çeşitlendirilmesi,

4. Mevcut parklarda bulunan canlı ve cansız materyalin nitelik ve nicelik bakımdan iyileştirilmesi,

5. Kent parkları veya çocuk oyun alanları için 500-750 m erişilebilirlik mesafesine göre gerekli iyileştirilmenin yapılması,

6. İmar planında park, rekreasyon alanı, açık alan olarak gösterilen alanların korunarak aktif yeşil alan olarak değerlendirilmesi, yeni yapılacak parkların evrensel peyzaj tasarım standartları doğrultusunda yapilmas1,

araştırma kapsamında önerilmiştir.

\section{Teşekkür}

Bu çalışma, Bingöl Üniversitesi, Bilimsel Araştırma Koordinatörlüğü’nün BAP-ZF.2018.00.011 Nolu projesi tarafından desteklenmiştir.

\section{Kaynaklar}

1. Atabeyoğlu, Ö., Bulut, Y. (2012). Ordu kenti mevcut yeşil alanlarının değerlendirilmesi. Akademik Ziraat Dergisi, 1:2 67-76.

2. Bahrinia, F., Bella, S., Mokhtarzadeh, S. (2017). The relationship between the distribution and use patterns of parks and their spatial accessibility at the city level: A case study from Tehran, Iran. Urban Forestry \& Urban Greening, 27 (2017) 332-342.

3. Bilgili, C.B., Çı̆̆, A., Şahin, K. (2011). Van kenti kamusal yeşil alanlarının yeterliliğinin ulaşılabilirlik yönünden değerlendirilmesi. Yüzüncü Yıl Üniversitesi Tarım Bilimleri Dergisi, 21:2 98-103.

4. Creswell, J. W., Plano-Clark, V. L. (2007). Designing and Conducting Mixed Methods Research. Thousand Oaks, CA: Sage Publication.

5. Çıngı, H. (1994). Örnekleme Kuramı, Ankara: Hacettepe Üniversitesi Fen Fakültesi Basımevi. 
6. Demiroğlu, D., Yucekaya, M., Günaydın, A.S., Taşçıglu, S. (2017). Ecological approach to urban parks: The case of urban parks in Kilis, Turkey. Feb-Fresenius Environmental Bulletin, 26:12 7142-7149.

7. Duymuş, B., Yurtkoru, E.S., Çinko, M. (2012). Sosyal Bilimlerde SPSS'le Veri Analizi. Beta Yayınları, 4.Bask1, 215s, İstanbul.

8. Doygun, H., Atmaca, M., Zengin, M. (2015). Kahramanmaraş’ta kentleşme ve yeşil alan varlığındaki zamansal değişimlerin incelenmesi. Kahramanmaraş Sütçü İmam Üniv. Doğa Bilimleri Dergisi, 18:4 5561.

9. Grahn, P., Stigsdotter, U.A. (2003). Landscape planning and stress. Urban Forestry and Urban Greening, 2: 1-18.

10. Gül, A., Küçük, V. (2001). Kentsel açık-yeşil alanlar ve Isparta kenti örneğinde irdelenmesi. Süleyman Demirel Üniversitesi Orman Fakültesi Dergisi, A:2 27-48.

11. Gürer, N., Uğurlar, A. (2017). Kent parklarında kullanıcı memnuniyeti: Ankara Kuğulu Park Örneği. Megaron, 12:3 443-459.

12. Olgun, R. (2019). Orta ölçekli kentler için kentsel yeşil alan sistem önerisi: Niğde Kenti Örneği. Artium, 7:1 57-69.

13. Onsekiz, D., Emür, S.H. (2008). Kent parklarında kullanıcı tercihler ve değerlendirme ölçütlerinin belirlenmesi. Sosyal Bilimler Enstitüsü Dergisi, 24:1, 69-104.

14. Manavoğlu, E. (2013). Antalya Kenti Yeşil Alanlarının Çok Ölçütlü Analizi ve Planlama Stratejilerinin Geliştirilmesi. Akdeniz Üniversitesi Fen Bilimleri Enstitüsü, Yayınlanmamış Doktora Tezi, 281s.

15. Manavoğlu, E., Ortaçeşme, V. (2015). Antalya kenti yeşil alanlarının çok ölçütlü analizi ve planlama stratejilerinin geliştirilmesi. Mediterranean Agricultural Sciences, 28:1, 11-19.

16. Morancho, A.B. (2003). A hedonic valuation of urban green areas. Landscape and urban planning, 66:1, $35-41$.

17. Önder, S., Polat, A.T. (2012). Kentsel açık-yeşil alanların kent yaşamındaki yeri ve önemi. Kentsel Peyzaj Alanlarının Oluşumu ve Bakım Esasları Semineri, Konya, 73-96.

18. Öztürk, S., Özdemir, Z. (2013). Kentsel açık ve yeşil alanların yaşam kalitesine etkisi 'Kastamonu Örneği'. Journal of Kastamonu University Faculty of Forestry, 13:1 109-116.

19. Saphores, J.D., Li, W. (2012). Estimating the value of urban green areas: A hedonic pricing analysis of the single family housing market in Los Angeles, CA. Landscape and Urban Planning, 104:3-4 373-387.

20. TÜİK (2019). Türkiye İstatistik Kurumu Adrese Dayalı Nüfus Kayıt Sistemi Sonuçları (http://tuik.gov.tr/Start.do, Erişim tarihi; 25.07.2019).

21. Ülger, F.N., Önder, S. (2006). Kayseri kenti açık-yeşil alanlarının nitelik ve nicelik açısından irdelenmesi. Selçuk Tarım ve Gıda Bilimleri Dergisi, 20(38), 108-118.

22. Yavuz, A., Eminağaoğlu, Z. (2007). Artvin kentinde yeşil alanların yeterlilik bakımından irdelenmesi, TMMOB Harita ve Kadastro Mühendisleri Odası Ulusal Coğrafi Bilgi Sistemleri Kongresi, 30 Ekim -02 Kasim 2007, KTÜ, Trabzon.

23. Yenice, M.S. (2012). Kentsel yeşil alanlar için mekânsal yeterlilik ve erişilebilirlik analizi; Burdur örneği, Türkiye. SDÜ Orman Fakültesi Dergisi SDU Faculty of Forestry Journal, 2012, 13: 41-47.

24. Yılmaz, S., Bulut, Z., Yeşil, P. (2006). Kent Ormanlarının Kentsel Mekâna Sağladığı Faydalar. Atatürk Üniversitesi Ziraat Fak. Dergisi, 37 (1), 131-136. 